\title{
Anomuran and brachyuran trackways and resting trace from the Pliocene of Valduggia (Piedmont, NW Italy): environmental, behavioural, and taphonomic implications
}

\author{
Giovanni Pasini ${ }^{1}$, Angela Baldanza ${ }^{2}$, Lorenzo M. Gallo ${ }^{3}$, \\ Alessandro Garassino ${ }^{4 *}$, Hiroaki Karasawa ${ }^{5}$
}

\begin{abstract}
We report a rich ichnofacies including trackways and a resting trace made by indeterminate anomuran and brachyuran crabs, and other organic sedimentary structures produced by invertebrates. This is the first fossil record of crab trackways and resting trace in a shoreface intertidal environment from the Pliocene sediments of Valduggia area (Vercelli, Piedmont, NW Italy). Behavioural and palaeoenvironmental data allow reconstruction of the possible scenario of the upper shoreface surface in this area of the northern paleo-Adriatic Gulf during the Pliocene. The resting trace is tentatively compared to the rehydrating and respiration behaviour of a semiterrestrial (?Ocypodidae) crab, documented for the first time in the fossil record. A single trackway is tentatively assigned to the locomotion of a land hermit $\mathrm{crab}$, the first such fossil record from the paleo-Mediterranean area. Moreover, among other invertebrate burrows, hypichnal Halopoa $\mathrm{cf}$. H. imbricata is reported in shallow marine deposits for the first time. Palaeontological, petrological, sedimentological, taphonomic, and ethological implications are discussed and compared with neoichnological data. This notable discovery enlarges our scant knowledge on the palaeo-ichnology of decapod crustaceans.
\end{abstract}

Key words: Anomura, Brachyura, Decapoda, trackways, resting traces, ichnofacies, Pliocene, Italy.

Riassunto - Tracce di locomozione di un anomuro, di brachiuri e di un'impronta di sosta nel Pliocene di Valduggia (Vercelli, Piemonte, Italia nordoccidentale): implicazioni ambientali, comportamentali e tafonomiche.

\footnotetext{
${ }^{1}$ Via Alessandro Volta 16, 22070 Appiano Gentile (Como), Italia. E-mail: juanaldopasini@tiscali.it

2 Dipartimento di Fisica e Geologia, Università degli Studi di Perugia, Piazza Università 1, 06123 Perugia, Italia.

E-mail: angela.baldanza@unipg.it

${ }^{3}$ Museo Regionale di Scienze Naturali, Sezione di Mineralogia, Petrografia e Geologia, Via Giolitti 36, 10123 Torino, Italia.

E-mail: lorenzom.gallo@regione.piemonte.it

${ }^{4}$ Sezione di Paleontologia degli Invertebrati, Museo di Storia Naturale, Corso Venezia 55, 20121 Milano, Italia.

${ }^{5}$ Mizunami Fossil Museum, Yamanouchi, Akeyo, Mizuanmi, Gifu 509-6132, Japan.

E-mail: GHA06103@nifty.com

* Corresponding author: alessandro.garassino@comune.milano.it alegarassino@gmail.com
}

(C) 2016 Giovanni Pasini, Angela Baldanza, Lorenzo M. Gallo, Alessandro Garassino, Hiroaki Karasawa

Received: 29 February 2016

Accepted for publication: 7 April 2016
Viene segnalata una ricca icnofacies del Pliocene di Valduggia (Vercelli, Piemonte, Italia nordoccidentale) che comprende alcune piste di locomozione, un'impronta di sosta di brachiuri indeterminati, una pista attribuibile ad un paguride e alcune tracce prodotte dall'attività di altri invertebrati. È la prima segnalazione nel record fossile pliocenico mondiale di piste fossili collegate ad una traccia di sosta conservatesi in un ambiente costiero intertidale. I dati desunti sul comportamento e sul paleoambiente permettono una ricostruzione del possibile scenario lungo una spiaggia del golfo paleo-Adriatico durante il Pliocene. In particolare le piste e l'impronta di sosta sono interpretate come dovute al possibile comportamento di reidratazione/respirazione di un crostaceo semiterrestre (?Ocypodidae), mai documentato nel record fossile. Una singola pista è invece attribuita al movimento di un paguride terrestre indeterminato, prima segnalazione fossile nell'area Paleo-mediterranea. Inoltre fra le altre tracce presenti riferibili a diversi invertebrati, è documentata la presenza di una pista attribuita a Halopoa $\mathrm{cf}$. $H$. imbricata, prima segnalazione di questa icnospecie in depositi marini poco profondi. I dati paleontologici, petrologici, sedimentologici, tafonomici e etologici sono stati discussi e comparati con gli attuali dati neo-icnologici disponibili. Questa importante nuova scoperta allarga notevolmente le scarse conoscenze sulla paleo-icnologia dei crostacei decapodi.

Parole chiave: Anomura, Brachyura, Decapoda, piste di locomozione, impronta di sosta, icnofacies, Pliocene, Italia.

\section{INTRODUCTION}

Marine brachyuran crustacean trackways are scarce in the fossil record. Noda \& Okamoto (1988) reported some "crustacean raking imprints" from the upper Oligocene Taoyama Formation (southwest Japan), ascribed to indeterminate crustaceans though not referable, in our opinion, to brachyuran crabs. Karasawa et al. (1990) reported trackways from the lower Miocene Mizunami Group (central Japan), probably produced by the two predominant brachyuran species, Miosesarma japonicum Karasawa, 1989, and Carcinoplax antiqua (Ristori, 1889), based “...upon width of four paired imprints..." (Karasawa et $a l ., 1990)$. The tracks are preserved on a flat planes of tuf$\mathrm{fs}$ "...considered to have been deposited in about $60 \mathrm{~m}$ of water depth based upon the mollusk fossil assemblage..." (Karasawa et al., 1990). Matsuoka et al. (1993) reported some quite similar "crab-footprints" (and burrows), from the lower Miocene Shidara Group (central Japan). Dam (1990: 141-142) reported and figured a single trackway (Type 2) "...tentatively interpreted as representing a sideways trackway of a crab crossing a rippled subtidal sandflat...", from the shallow marine lower Jurassic of 
East Greenland. Pirrie et al. (2004) described a crustacean trackway from shallow marine deposits of the late Cretaceous (Coniacian) Hilden Lake Formation of James Ross Island, Antarctica, assigned to the ichnospecies $\mathrm{Fo}_{\mathrm{O}}$ ersterichnus rossensis and interpreted as to be related to a brachyuran decapod trace-maker. De \& Mathur (2007) reported some Quaternary trackways of crustacean origin from the Banas Basin of Gujarat, in western India. Recently, De (2014) reported one ten-meter long unnamed trackway from the Eocene of the Mithakhari Group in the Andaman Islands, Bay of Bengal, India that "...constitute ancient analogues of the extant Ocypode trackways reported from the Bay of Bengal Coast...".

Scarcer are trackways assigned to land hermit crabs in the fossil record. Indeed, just one trackway is known to date from the early Holocene of San Salvador Island (Bahamas) and ascribed to the ichnospecies Coenobichnus currani (Walker et al., 2003).

Fossil exogenic traces related to the activities of terrestrial brachyuran and anomuran crustaceans from upper shoreface environments are rarely reported in the fossil record "...because their potential preservation is quite low as a result of wave, tidal, wind, and rain erosion..." (Martin, 2006: 58). Imaizumi (1967: 207, fig. 3) reported a trackway partially crossing "...wetted silt and dried sand or silt...", ascribed to a brachyuran shore crab [possibly comparable with those made by the extant Helice tridens tridens (De Haan, 1835)] from the lower Pliocene of the Tatsunokuchi Formation (Miyagi Prefecture, northeast Japan). For instance, fossil burrows (Psilonichnus), firmly attributed to ocypodid crabs, have been reported from the Pleistocene and Holocene upper shoreface facies of the Georgia barrier islands (Frey \& Pemberton, 1987; Frey \& Howard, 1988) and San Salvador (Bahamas) (Curran, 1984). Similarly, Garassino et al. (2010) reported the presence of vertical cylindrical burrows in an (upper) shoreface environment from the Pliocene (Piacenzian) of Tuscany, probably related to the activity of the as- sociated semiterrestrial brachyuran crab Ocypode italica Garassino, De Angeli, Pasini \& Tangocci, 2010.

Based upon these previous reports, the discovery of brachyuran trackways in the shoreface layers from the Valduggia (Piedmont, Italy) is very important since it represents the first report of a clear and rich ichnofacies related to the locomotion of semiterrestrial decapod crabs in the Pliocene of the Mediterranean area. Furthermore, the first documented resting trace possibly recording rehydrating and respiration behaviour allows comparison with related neoichnological data, suggesting palaeontological, sedimentological, taphonomic, and ethological hypotheses. Finally, a possible land hermit crab trackway, reported for only the second time in the fossil record, represents the oldest ichnological evidence known to date.

\section{GEOLOGICAL SETTING AND \\ PALAEONTOLOGICAL CONTENT}

The Valduggia village is located in the lower Valsesia Valley along the right side of the Strona River in the southern Prealps, within the Vercelli Province (Piedmont, NW Italy) $\left(45^{\circ} 43^{\prime} 29^{\prime \prime} \mathrm{N}, 8^{\circ} 18^{\prime} 52^{\prime \prime} \mathrm{E}\right)$ (Fig. 1). Pliocene marine deposits only locally crop out, preserved in incised valleys, representing the most recent sediments of the marine succession deposited at the foot of the Western Alps and showing that the main valleys of the Western Alps already existed before transgression of the sea during the early Pliocene (Carraro, 1992). At Formigosa, at an elevation of about $400 \mathrm{~m}$ a.s.l., an intermittent creek crosses a Pliocene marginal-marine lithographic sequence including stratified, fine-grained grey clayey sands (Fig. 2A). The well-laminated and stratified clayey sands are overlapped by non-laminated yellow and grey beds (Fig. 2B) preserving a macrofossil assemblages including irregular echinoids, plant remains (including leaves), and very rare, small gastropods as well as a marine decapod brachyuran crab, Ethusa sp., in the uppermost part of the

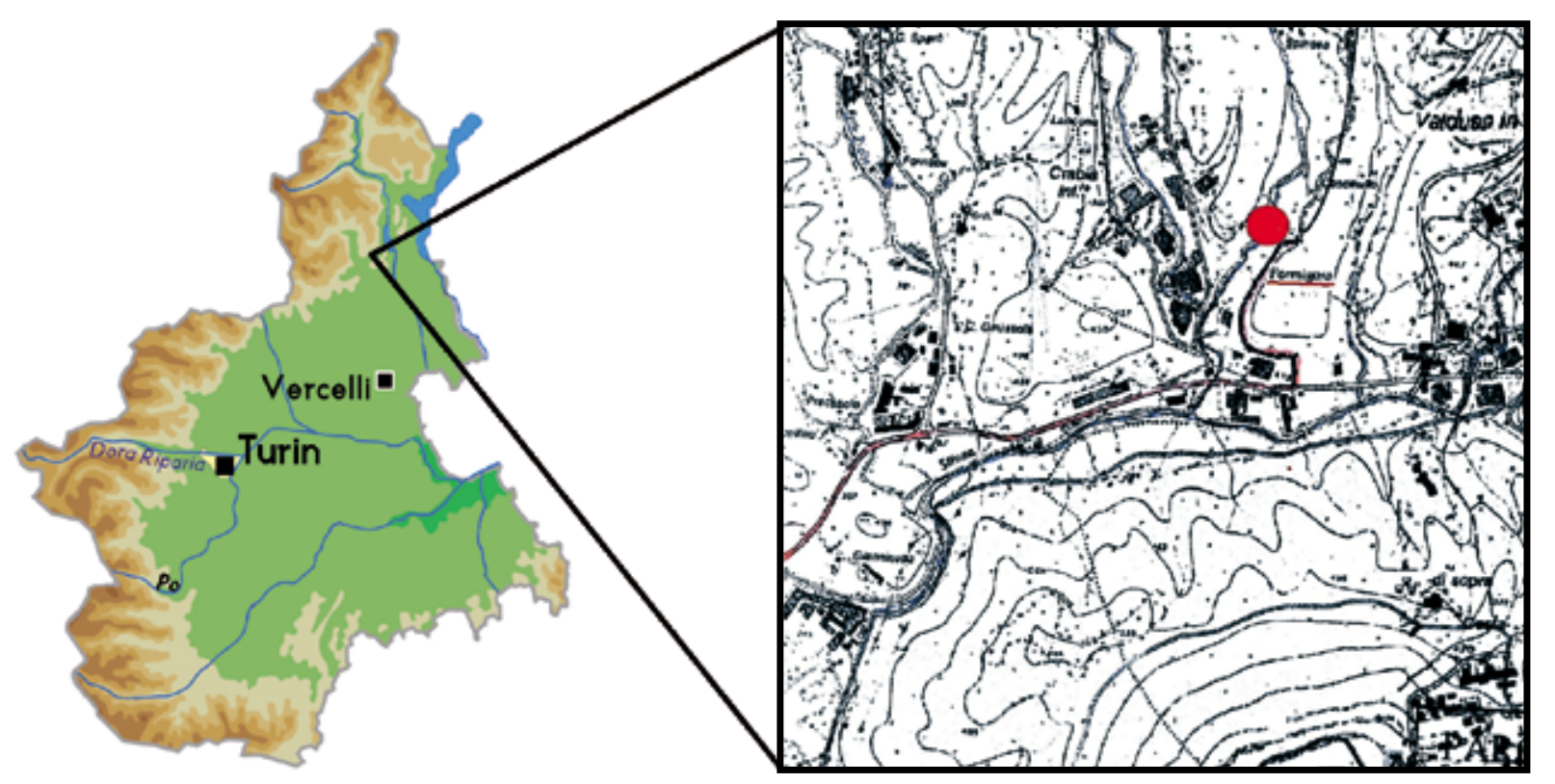

Fig. 1 - Geographical map of the fossiliferous locality (in red). 
beds (Pasini, pers. obs., 2009; Pasini \& Garassino, 2016) (Fig. 3A-C). The samples were discovered along a small waterfall, exposed by natural erosion, or were detected by opening the stratified eroded layers at different levels of the laminated sequence. The fine-grained laminated layers, exposed for about $50 \mathrm{~cm}$ in thickness, indicate a temporary intertidal environment on upper shoreface surface where the trace-makers were active. No crab body remains or other associated fauna were observed in these laminated layers.
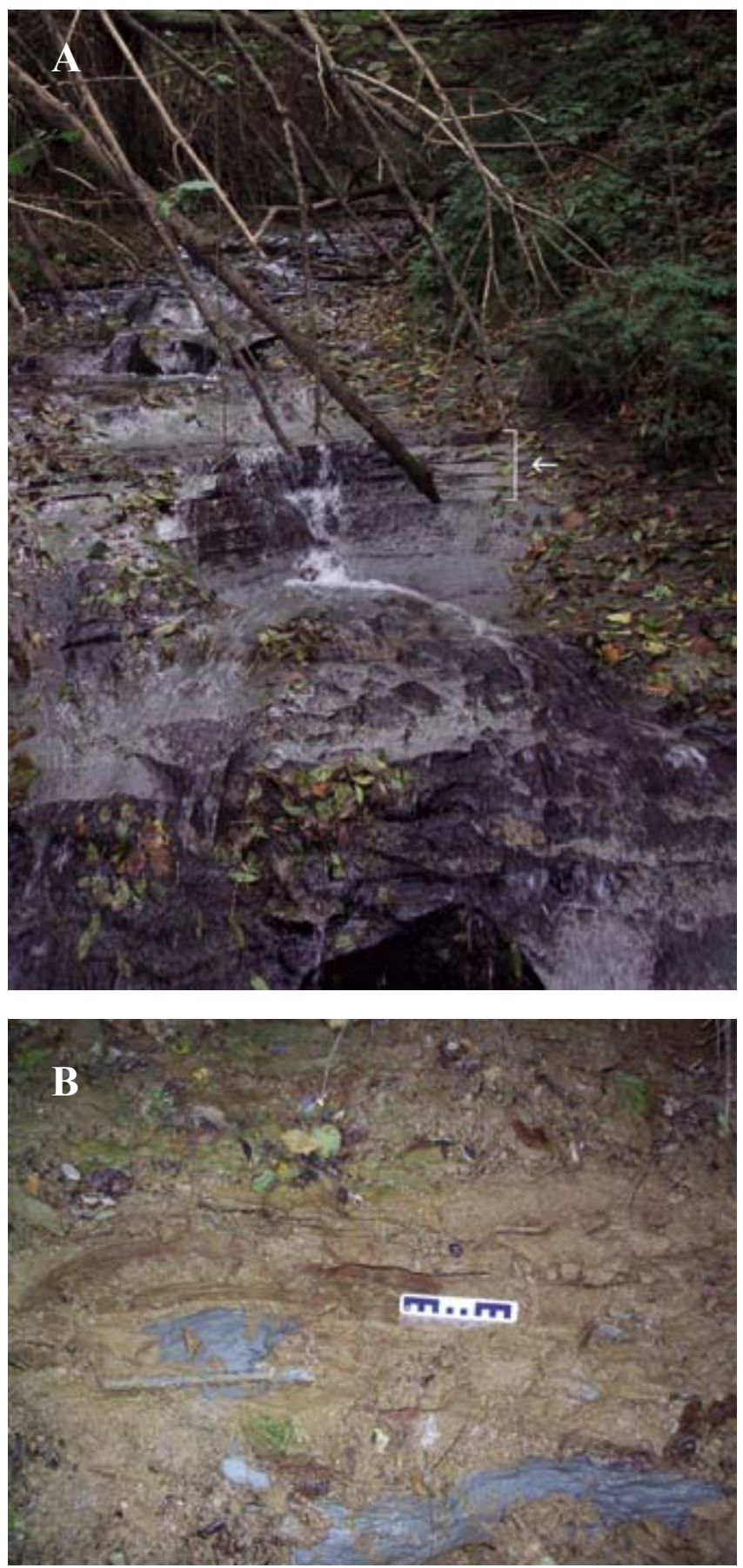

Fig. 2 - A) The waterfall section in Formigosa locality where the specimens were discovered, with the fossiliferous laminated layers $(\leftarrow)$. B) The upper non-laminated yellow and grey beds fossil assemblage.
Samples from the fine-grained laminated layers were processed for thin sections and micropalaeontological washed and smear slide preparations with the aim to identify microfossils and calcareous nannofossils useful for a precise age determination.

Unfortunately, all samples proved to be sterile and lacking of microfossils and calcareous nannofossils. Only
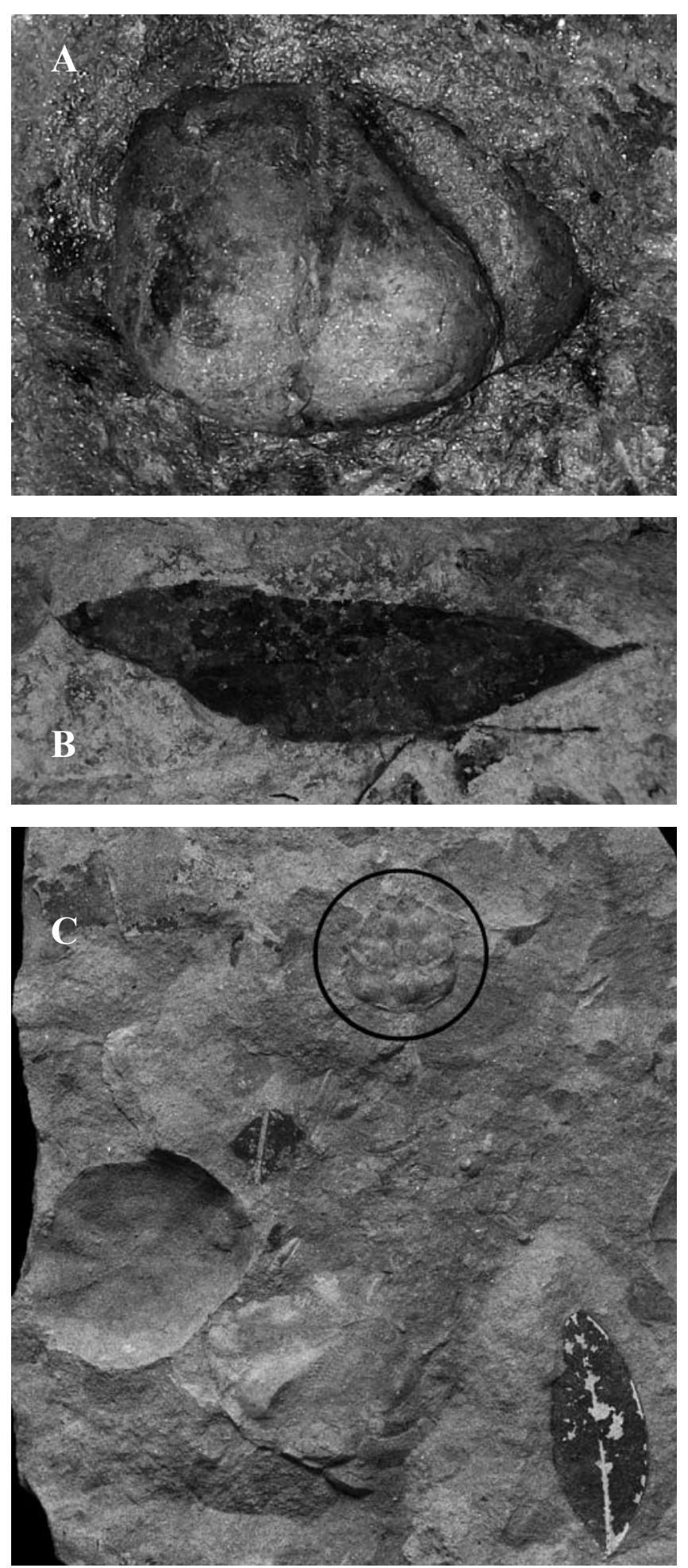

Fig. 3 - A) Indeterminate irregular echinoid. B) indeterminate angiosperm leaf. C) Ethusa sp., carapace in dorsal view. 
rare plant remains (frustules and carbonaceous fragments) were identified in washed residues.

The occurrence of rare fragments and imprints of gastropods referable to Bittium sp., an epibenthic microalgae herbivorous gastropod that lives in neritic supra-littoral to littoral zones and that generally occurs at low tide mark, indicates the existence of a sea bottom covered in microalgae that was emergent at low tide.

Sedimentary microstructures visible under optical polarizing microscope in thin sections exhibited the alternation of silts and fine sands arranged in subhorizontal laminations with small wave ripples (Fig. 4A), signifying an intertidal palaeoenvironment with medium to low flow regime, most likely related to a mixed (silt/sand) flat-sand flat. One slab (MSNM i28046) shows several microripples produced by low-energy wave action (Fig. 19).

These sparse analytical data allow us to identify a palaeoenvironment in which environmental conditions could be optimal for the formation and preservation of resting and walking crab traces. The abundance of plant remains (frustules and small coal fragments) testifies to the proximity of a vegetated continental area and supports the existence of a coastal palaeoenvironment rich in nutrients where decapods proliferated. According to Carraro (1992), and in the absence of closer micropalaeontological data, the studied specimens are here ascribed to the Pliocene in general terms.

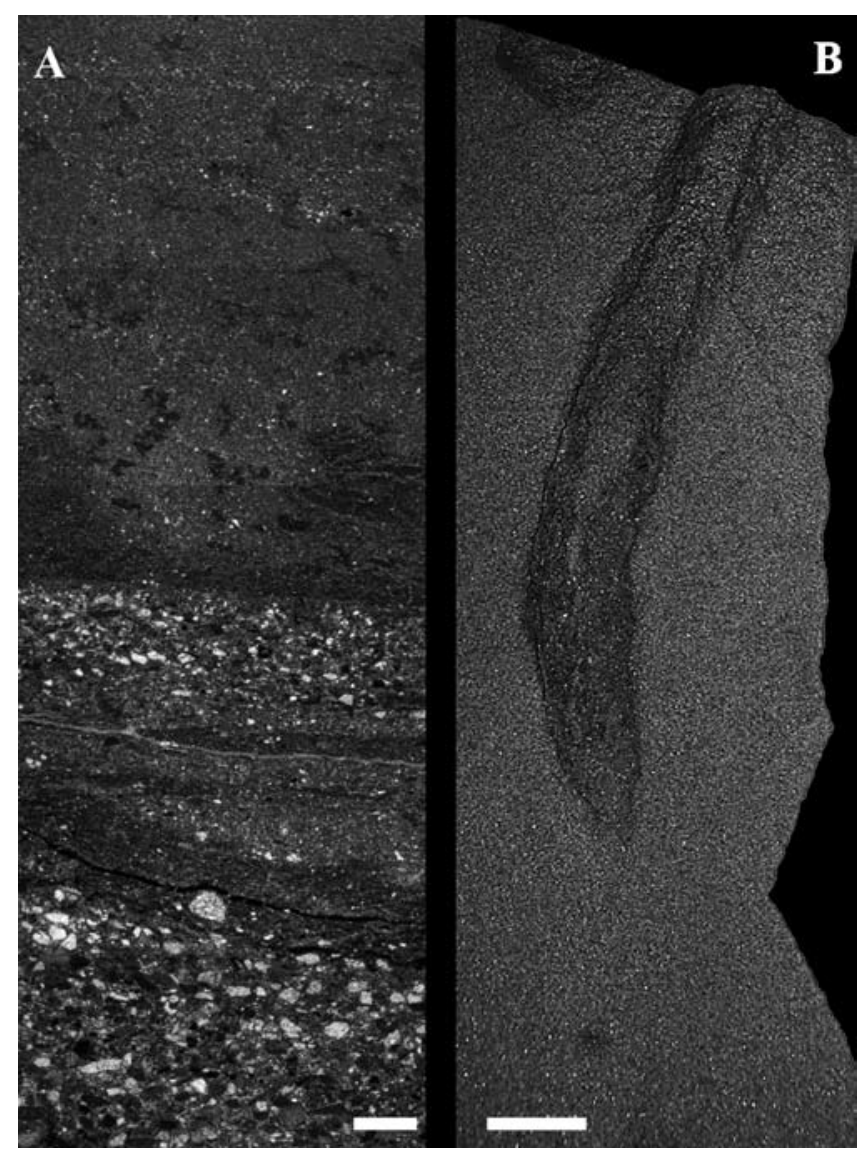

Fig. 4 - A) Thin section microphoto of sandy-silty level with interlayered very fine sands and silts, rich in organic matter and plant remains organized in micro-ripple structure, scale bar: $1 \mathrm{~mm}$. B) Halopoa cf. H. imbricata Torell, 1870 from the silty-sandy level (MSNM i28301), scale bar: $1 \mathrm{~mm}$.

\section{MATERIALS AND METHODS}

The studied sample includes 13 specimens, related to different ichnofacies, preserved in parts or counterparts as epi- or hyporelief (sensu Seilacher, 1964), on small to medium-sized, irregular slabs ranging about from $120 \times$ $90 \mathrm{~mm}$ to $540 \times 230 \mathrm{~mm}$ of fine grey sand. Due to the delicate thin nature of the sandy matrix, all slabs were fixed with a film of polyvinyl acetate for study and preservation. Photos of the most significant slabs were taken under natural and/or low light to emphasize the structures. The specimens are housed in the palaeontological collections of the Museo di Storia Naturale di Milano (MSNM).

\section{Measurements, abbreviations, symbols}

Some measurements were made on the single trackways as the maximum step length (L), here explained as the width sequence behind three series of imprints; and the track width $(\mathrm{W})$, measuring the distance among the $1^{\text {st }}$ and $4^{\text {th }}$ walking leg imprints, useful to evaluate the possible size and speed of displacement. The midline of some trackways was traced (hypothetically calculated crossing behind the $2^{\text {nd }}$ and the $3^{\text {th }}$ walking legs), with a broken line $(\mathrm{m})$, to emphasize the winding trend of the trace-maker; whereas the direction of the displacement is shown by an arrow $(\rightarrow)$. Ripplemarks are indicated by a double wave $(\approx)$ (Fig. 5).

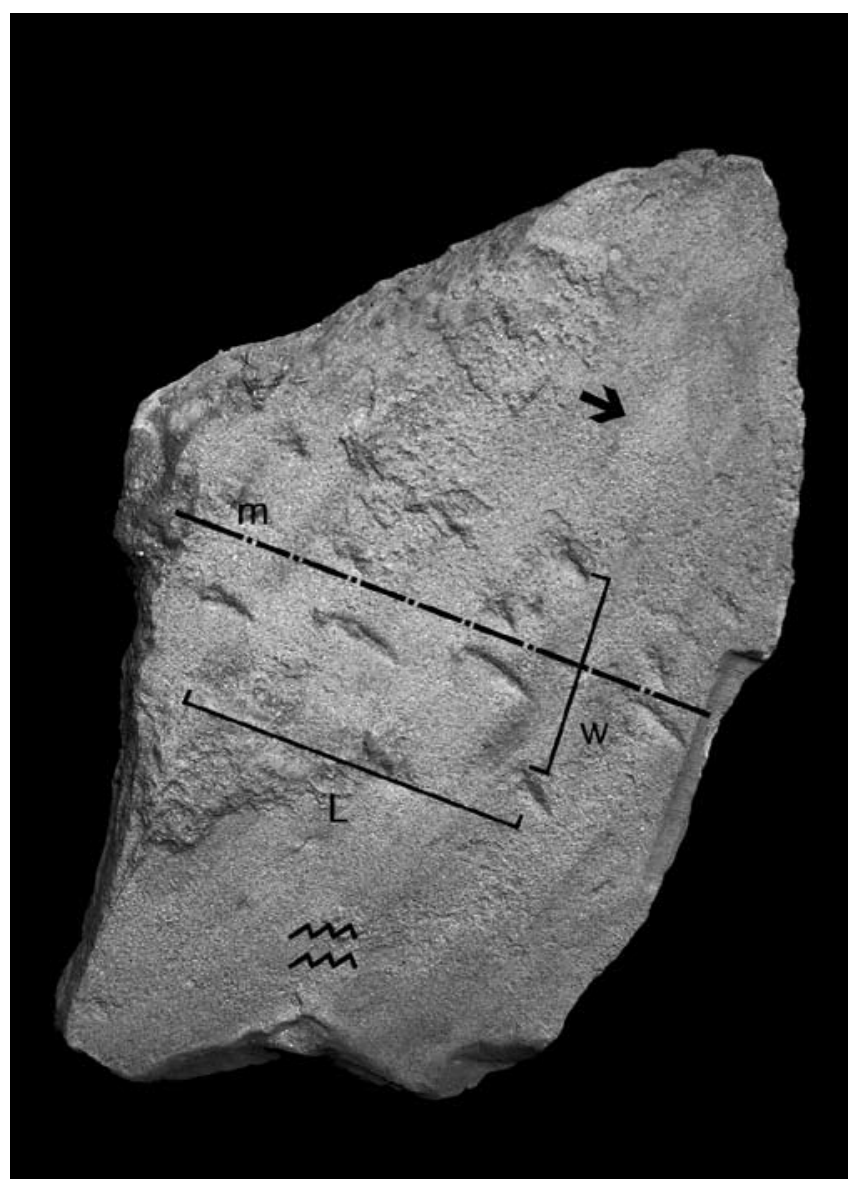

Fig. 5 - Explain of the measurements checked on the trackways (L: maximum step length; $\mathrm{W}$ : maximum width; $\mathrm{m}$ : middle line of the track), and symbols $[(\rightarrow)$ direction of the displacement; $(\approx)$ ripple marks $)]$ referred in the figures. 


\section{DESCRIPTION AND INTERPRETATION}

Arthropod trackways (Repichnia) - 7 specimens [(MSNM i28016, slab $160 \mathrm{~mm} \times 110 \mathrm{~mm}$; MSNM i28018 (front \& rear), slab $240 \mathrm{~mm} \times 160 \mathrm{~mm}$; MSNM i28022 (front \& rear), slab $290 \mathrm{~mm} \times 180 \mathrm{~mm}$; MSNM i28023, slab $180 \mathrm{~mm} \times 140 \mathrm{~mm}$; MSNM i28024 slab $120 \mathrm{~mm} \times$ $90 \mathrm{~mm}$; MSNM i28025, slab $170 \mathrm{~mm} \times 100 \mathrm{~mm}$; MSNM i28026, slab $540 \mathrm{~mm} \times 230 \mathrm{~mm}$.

Trackways are the most common structures in the studied samples, preserved as hypo- or epirelief. They represent the activity of different behaviours by differently sized individuals. They range from about $25 \mathrm{~mm}$ to $45 \mathrm{~mm}$ in maximum width (W) and from $20 \mathrm{~mm}$ to 55 $\mathrm{mm}$ in step length (L), indicating that different individuals at different growth stages (or different sexes) were active in this environment. Due to the collecting methods, the slabs bearing the trackways are incomplete, irregularly broken or only partially preserved, even though the traces are well marked and easy to identify. Some slabs show tracks on both exposed surfaces (front and rear), and they are reported simply with a single catalogue number.

The trackways show rhythmic, laterally asymmetric series of diagonal steps, parallel to one another or nearly overlapping, represented by four pairs of depressed, separate pits followed by elongate sand drop-like impressions laterally directed and produced by the extraction of the dactyli from the saturated sediment in the direction of movement $(\rightarrow)$, repeated several times, forming a long and more or less curved trail. First three pits are ranged along the arc of a circle, aligned diagonally with respect to the medial axis of the trackway (m), whereas the last four (representing the $4^{\text {th }}$, shorter walking leg) are shifted posteriorly, forming an angle with the nearly aligned others.

In some trackway a subrounded and irregular shallow accessory is preserved $5^{\text {th }}$ trace at the end of the first three lined pits (Fig. 6 front), but in other trackways only the tips of the imprints of three paired walking legs are present (Fig. 7). Moreover, other trackways are more chaotic and the pits nearly overlap one another, indicating different locomotory speed; in contrast generally different width of the tracks (W) indicates different body size of the tracemakers. The well-spaced, rhythmic four by four tracks, indicating slow locomotion, are the only useful ones for measurements, as in specimen MSNM i28022-front, when "...track sets overlap and become elongated with increased speed..." as directly observed by Martin (2006: 58) on Sapelo Island (Georgia, USA) in extant Ocypode trackways do not allow a clear interpretation of the movement. Moreover, three slabs (MSNM i28019, i28022-rear, i28023) preserve different intersecting trackways on the same surface, pertaining to different individuals, as they have different size and inferred movement and speed (Figs. 8-10). This could indicate great activity due to a large number of specimens that lived together.

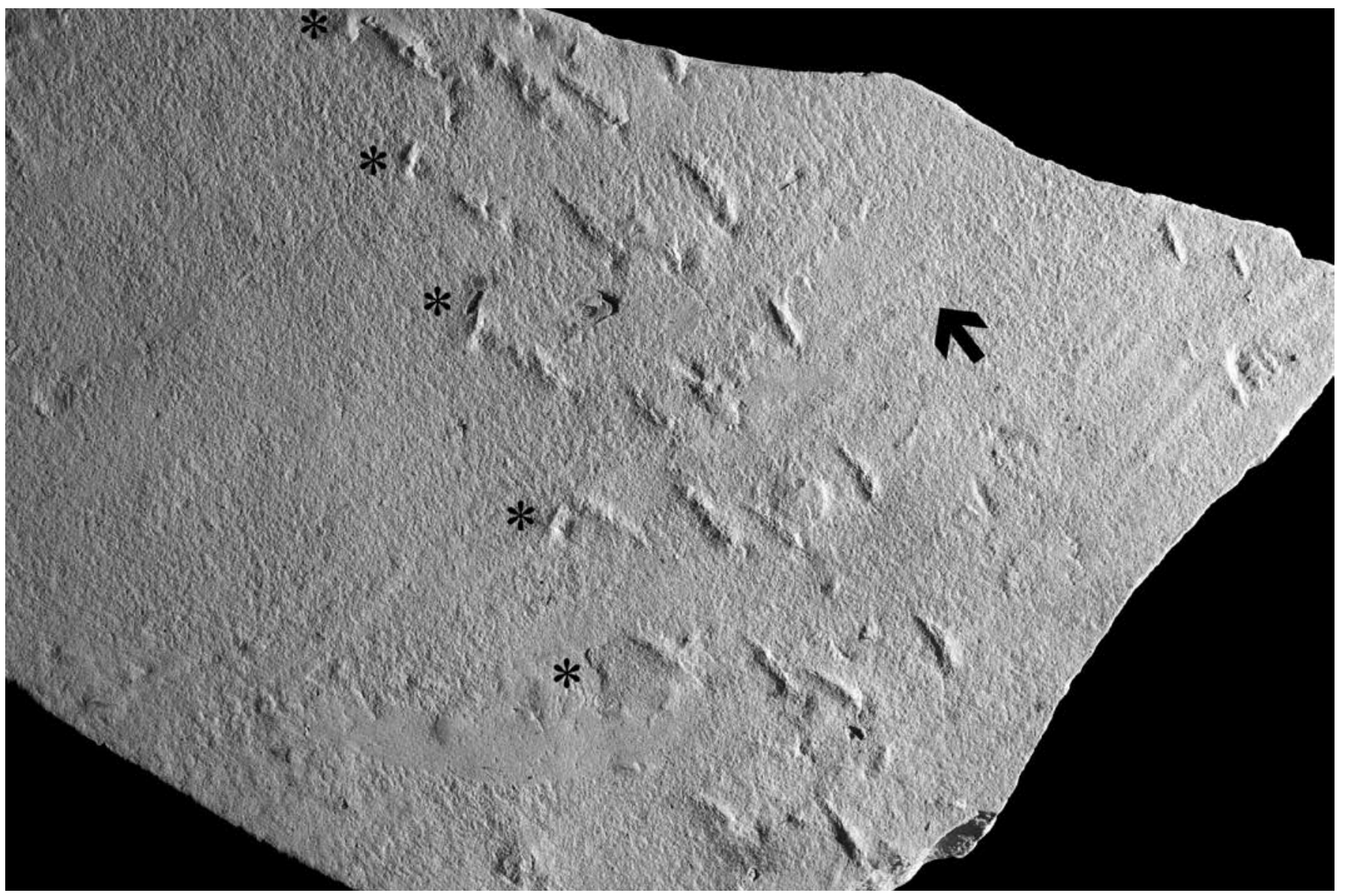

Fig. 6 - MSNM i28022 front. Rhythmic lateral complete trace series of diagonal steps of an indeterminate crab with the possible imprints of the chelipeds $(*)(\times 0.6)$. 


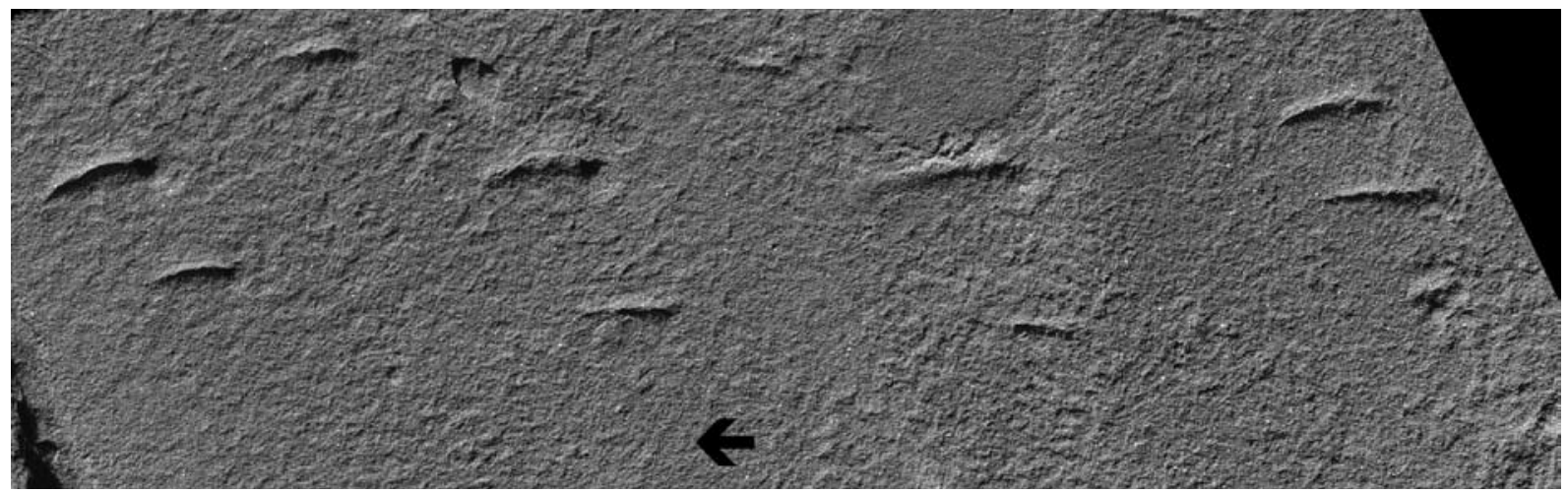

Fig. 7 - MSNM i28024. Crab trackway preserving imprints of the tip of only three paired walking legs $(\times 1.5)$.

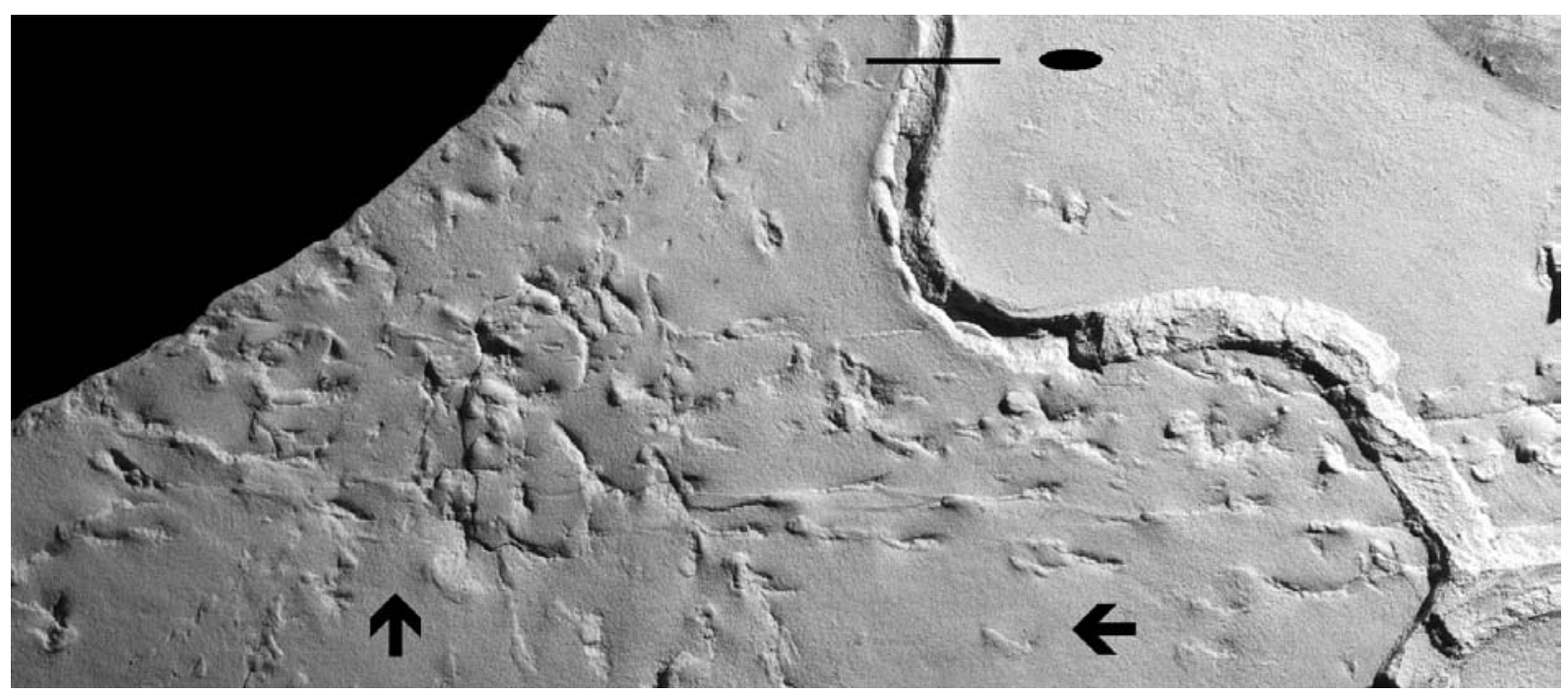

Fig. 8 - MSNM i28019. Intersecting crab trackways belonging to different individuals; one crossed by an exogenic mostly horizontal, sinuous and Y-shaped burrow (?"Thalassinoides") with subelliptical transverse section $(\times 0.5)$.

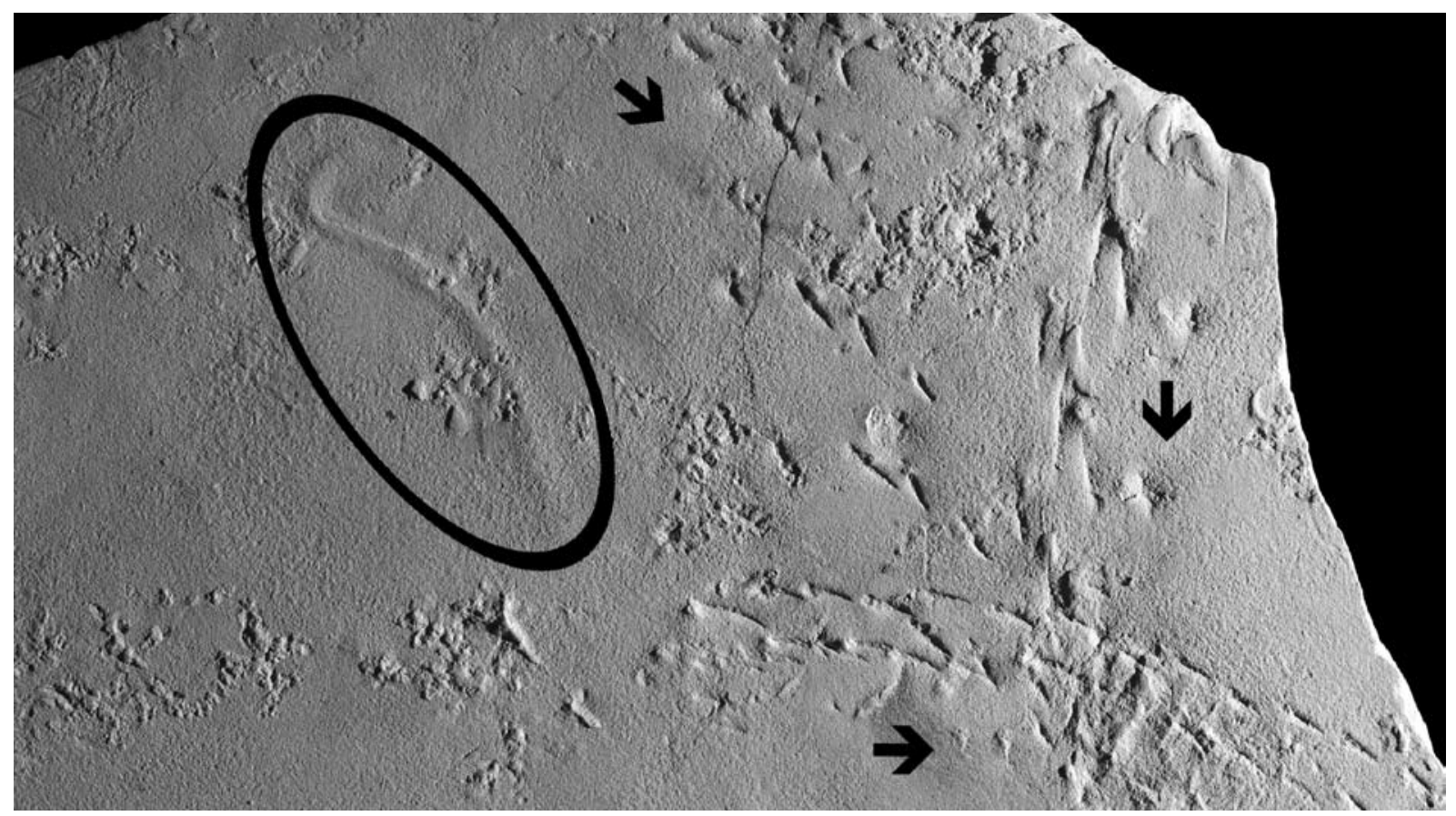

Fig. 9 - MSNM i28022 rear. Slab preserving intersecting crab trackways belonging to different individuals and a partial sinuous short trail rounded in transverse section $($ Pascichnia $)(\times 0.8)$. 


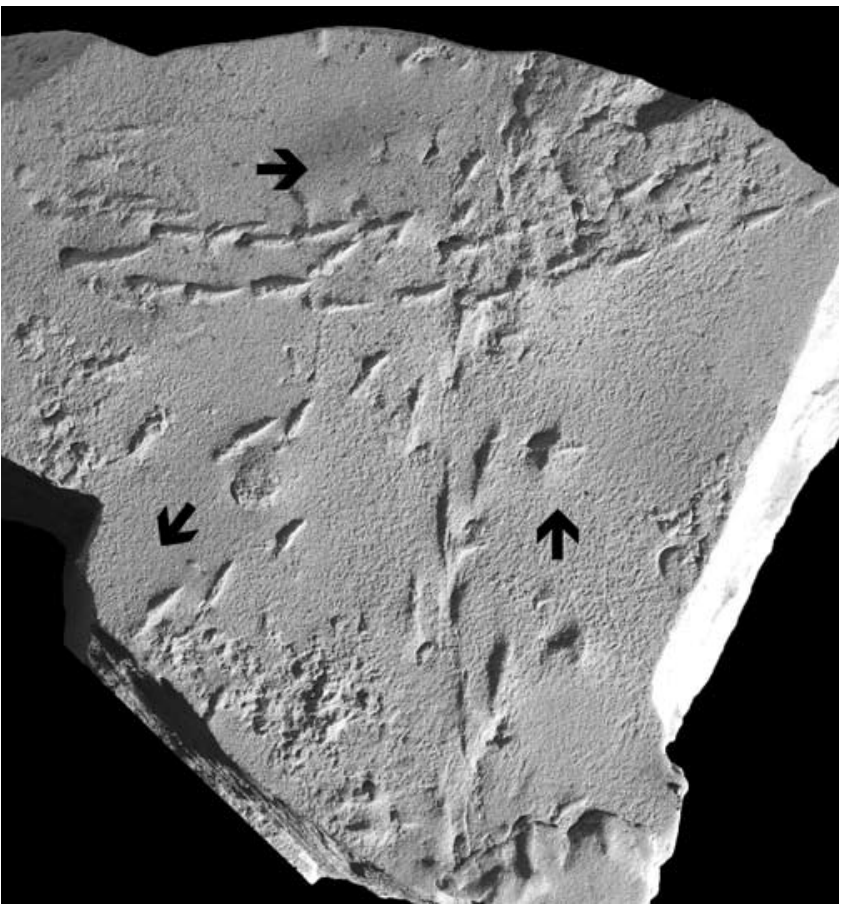

Fig. 10 - MSNM i28023. Intersecting trackway pertaining to almost three different crab individuals $(\times 0.6)$.

All these trackways are typical of the various activities of decapod crustaceans along an upper shoreface surface. Indeed, the presence of four paired pits fits well with the pointed form as the tips of the four dactyli of the functional walking legs moved laterally by the antagonist muscles, whereas the additional $5^{\text {th }}$ track may perhaps indicate the rest of the tip of the chelipeds into the sediment, having a feeding or sensory purpose (= chemoreceptors), or simply as hypothetical help in balancing during slow movement.

The lateral, more or less curved movement is also a common characteristic in decapod brachyurans such as ghost crabs (Full \& Blickhan, 1985: 25; Martin, 2006: 58). Among extant and fossil decapods, only some brachyurans and anomurans (land hermit crabs) have welldocumented semiterrestrial environment behaviours. The hermit crabs (pagurids) show a characteristically different imprint form in which the drag trace of the inhabited shell forms, usually (but not always), part of the trackway; also, in terrestrial hermit crabs only the two longer, asymmetric first legs have ambulatory function with the help of the chelipeds (Walker et al., 2003).

Based upon the palaeoenvironmental data (see in Geological setting and palaeontological content) and typology of trackways, is possible that the studied trackway might be, for example, compared with the extant activity of ocypodids (Crustacea, Brachyura) on the intertidal zones as reported by Martin (2006). Unfortunately, no fossil Ocypode remains have been reported to date from the Pliocene of Piedmont or along the paleo-Adriatic gulf of the Mediterranean Sea to confirm this hypothesis. The only fossil species known to date is Ocypode italica Garassino, De Angeli, Pasini \& Tangocci, 2010, discovered in yellow sands of a shoreface environment from Tuscany (central Italy) associated with burrowing evidence, possibly referred to the same species (Garassino et al., 2010). We have also considered that the studied sample could be related to a grapsid shore crab or to a terrestrial brachyuran belonging to the Geocarcinidae, but these hypotheses are unsupported to date by any report in the fossil record from the Pliocene of the Mediterranean Padanian Gulf.

The only brachyuran body remains reported to date from the Pliocene of the eastern Padanian Gulf (Piedmont) have been ascribed to the Calappidae H. Milne Edwards, 1837, Ethusidae Guinot, 1977, Goneplacidae MacLeay, 1838, Leucosiidae Samouelle, 1819, Majidae Samouelle, 1819, Pilumnidae Samouelle, 1819, Portunidae Rafinesque, 1815, Raninidae De Haan 1841, Retroplumidae Gill, 1894, and Xanthidae MacLeay, 1838; the anomurans include only the Paguridae Latreille, 1802 (for complete list see Garassino et al., 2004, Garassino \& Pasini, 2013; Pasini \& Garassino, 2009, 2013, 2015a, b, 2016). Based upon the known reports, brachyurans and anomurans can only be related to a marine palaeoenvironment. We point out that the absence of fossil remains of Ocypodidae from the Neogene deposits of Piedmont and the sediments along all the northern borders of the palaeo-Adriatic Gulf, may possibly due only to the poor report and scarce investigation on foreshore marine environments and its decapod fauna, instead of a real absence of representative of the family in this area.

If we compare the trackways to the similar fossil reports from the Coniacian (late Cretaceous) of Antarctica and from the Miocene and Pliocene of Japan, the general morphology and arrangement show more close affinities with the specimens reported by Imaizumi (1967: Pl. 17, fig. 6), Karasawa et al. (1990: Pl. 16, Type 2, figs. 2, 3), Matsuoka et al. (1993: 33, fig. 8), and least with those reported by Pirrie et al. (2004: 7, fig. 5), ascribed to the ichnospecies Foresterichnus rossensis. Among those, only the early Pliocene record by Imaizumi (1967) seems to be related partially to locomotion on a shoreline, whereas the other records are strictly related to marine brachyurans from different environments. Moreover, De (2014) cited "...one ten meters long unnamed trackway from the Eocene of the Mithakhari Group of Andaman Islands, Bengal Gulf, India...”, and De \& Mathur (2007) cited “...some Quaternary (Pleistocene-Holocene) trackways of crustacean origin from the Banas Basin of Gujarat, Western India..." that possibly "...constitute ancient analogues of the extant longest Ocypode trackways reported from the Bay of Bengal Coast...".

One short, chaotic track (MSNM i28025) shows a rapid, endless sweeping structure fan starting laterally from a central, subrounded indistinct trace (?burrow) (Fig. 11). This kind of activity resembles, in some way, the sweeping activity around their den of some semiterrestrial brachyuran decapods (for instance Ocypode, Uca, and Sesarma) in burrows near the tidal line as observable in subtropical beach environments (for instance, sandy beaches of the western coast of Nosy-Be Island, Madagascar (G. Pasini, pers. obs., 2001).

Three slabs (MSNM i28016, i28017, i28018 front) preserve one or more trachways related to the movement of brachyuran crabs crossing transversally a series 
of smooth ripplemarks (Figs. 12-14). Moreover, the slab (MSNM i28018 rear) preserves a single, short, different problematic trackway consisting of two parallel, alternate, subrounded aligned tips, extending parallel to a series of ripplemarks, that mostly seem produced by penetration into the substrate and due to the movement of a different indeterminate marine organism, similar to Saerichnites, a biostructure interpreted as made by mollusks (Billings, 1866) (see also: Uchman, 1998: 130, for emended diagnosis and remarks on this ichnogenus) (Fig. 15).

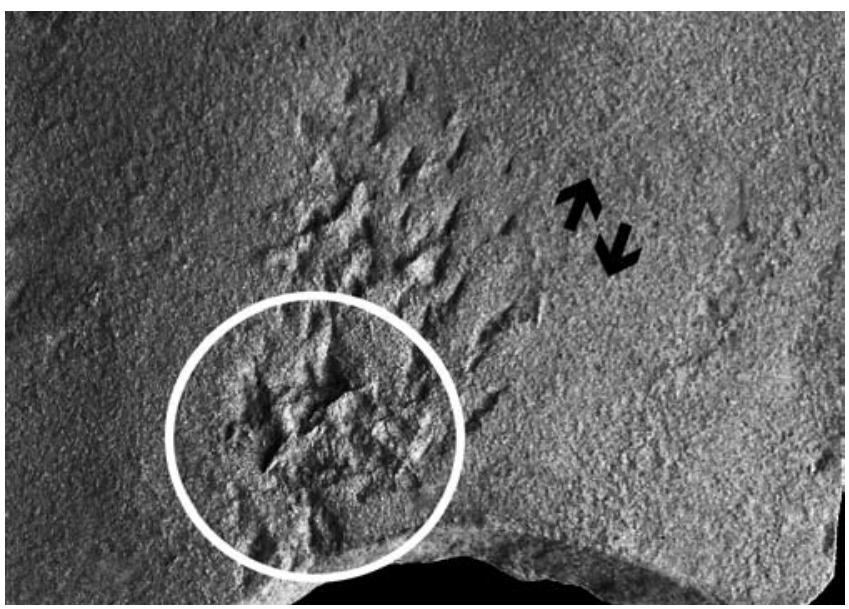

Fig. 11 - MSNM i28025. Chaotic crab trace showing a rapid endless sweeping structure fan from a central subrounded bioturbation (?burrow) $(\times 0.8)$.

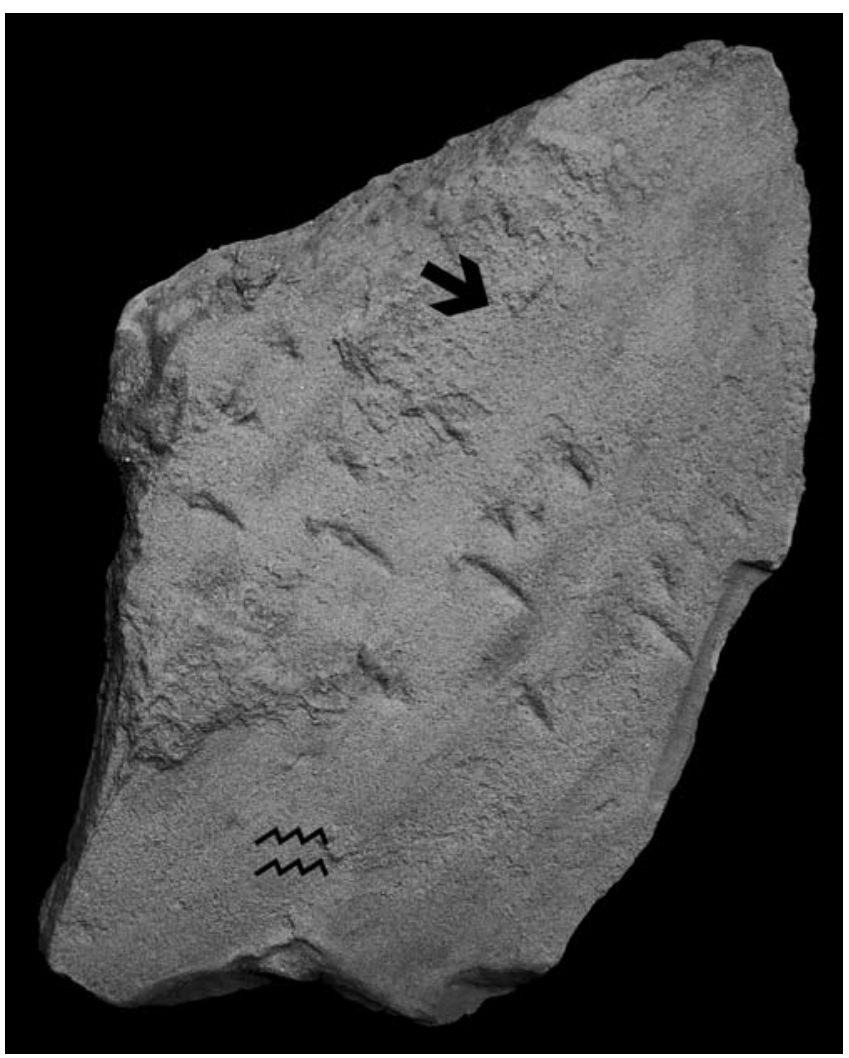

Fig. 12 - MSNM i28016. Short crab trackway crossing a series of smooth ripplemarks $(\times 0.6)$

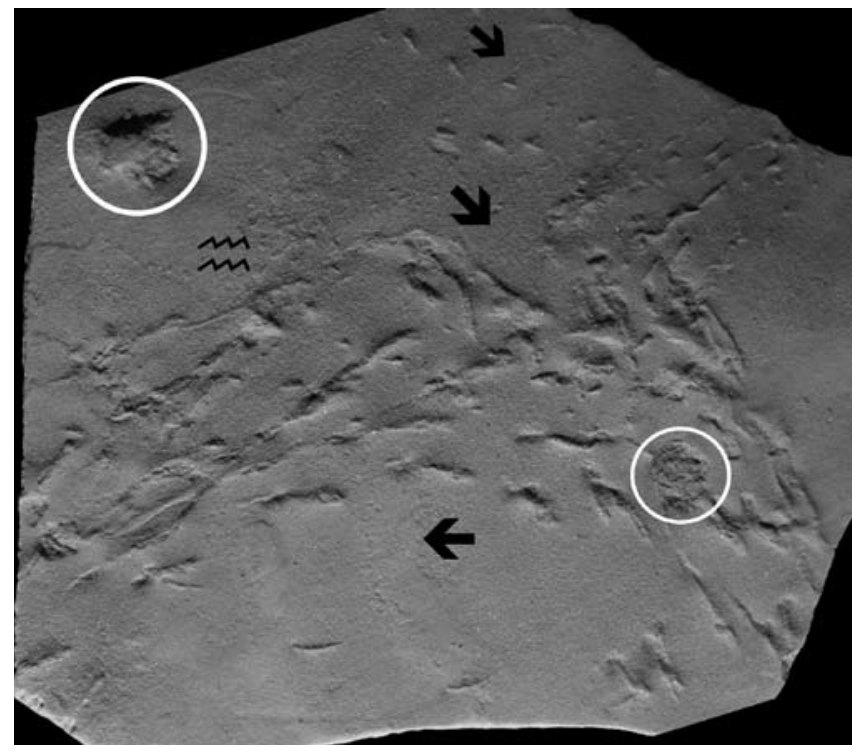

Fig. 13 - MSNM i28017. Slab preserving some crab trackways crossing a series of smooth ripplemarks track and two vertical subrounded burrows (?Skolithos) $(\times 0.4)$.

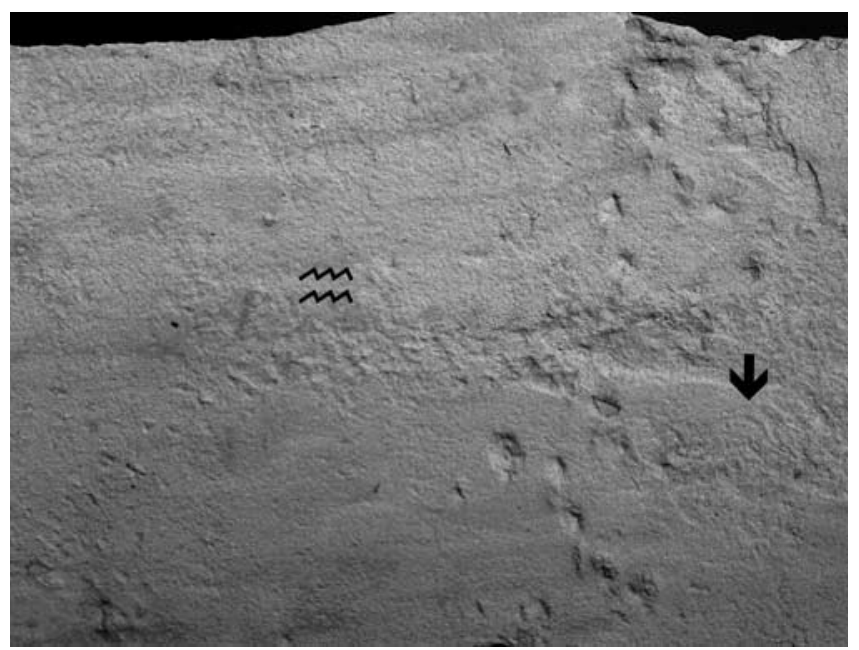

Fig. 14 - MSNM i28018 front. Crab trackway crossing a series of smooth ripplemarks $(\times 0.4)$.

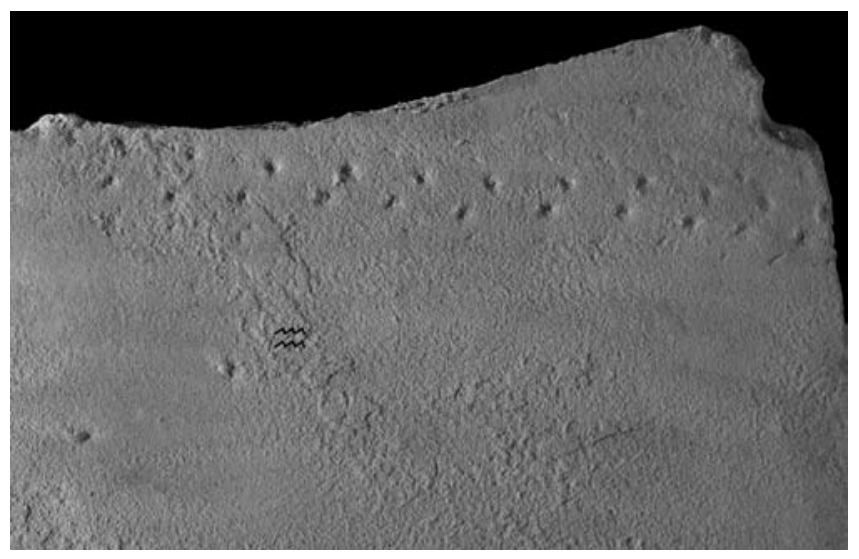

Fig. 15 - MSNM i28018 rear. Trace of an indeterminate marine organism (? mollusc), e.g. Saerichnites-like, moving parallel to a rim of ripplemarks $(\times 0.5)$. 
One wider slab (MSNM i28026, $540 \mathrm{~mm} \times 230 \mathrm{~mm}$ ), preserving a partial, well-defined straight, asymmetric, very wide trackway indicating a regular rhythmic tread (directed from right to left in Fig. 16). This trackway differs mainly from those previously described in size and arrangement showing a right and left asymmetry with a very light interior and less marked possible shell drag trace diagnostic of fossil and extant land hermit crab walking traces (Walker et al., 2003). We could compare the studied specimen with the only fossil record previously reported from the early Holocene of a backshore environment of San Salvador Island (Bahamas), ascribed to Coenobichnus currani, whose walking traces are very close "...to those of the extant Coenobita clypeata living along the Western Atlantic regions..." (Walker et al., 2003: 576). This ichnospecies, considering the different environment and nature of the substrate, recalls in some way, the general shape of movement and arrangement of the Pliocene studied specimen.

Arthropod trackway (Repichnia) and resting trace (Cubichnia): (MMSN i28020: $40 \mathrm{~mm} \times 32 \mathrm{~mm}$ ) (Fig. 17A, B).

This slab shows two single, divergent trackways arranged like those previously described at pag. 13, but interconnected to a well-impressed pleon and pereiopodresting trace pertaining to a decapod crab, all preserved as hyporelief. A subrectangular dwelling trace impression in the centre of the tracks corresponds to the ventral side of the carapace (estimated size of the carapace about $20-25 \mathrm{~mm} \times 15 \mathrm{~mm}$ ), wherein three pairs of linear, partially curved traces correspond to where the first three walking legs pressed onto the sediment, followed by a pair of smaller traces less well preserved that might indicate the fourth, shorter, posterior legs. On the opposite side of the carapace the impression of a pair of unequal, linear stronger imprints arranged parallel to the frontal margin, indicates the position of the chelipeds situated frontally (Fig. 17B). Both the interconnected walking tracks could be correlated to the same trace-maker. Indeed, the first indicates transverse movement from the upper side of the resting trace, whereas the second one is directed from the trace towards the left side of the slab (as gathered by the direction of the drop-like impressions), indicating a rotation of the body before leaving again, and forming an angle of about $45^{\circ}$ to the incoming trackway (Fig. 17B). This kind of track is very similar to the resting trace behaviours (rehydrating and respiration) reported by Martin (2006: 60, figs. 2A-D; 63, fig. $4 ; 2013$ ) from the shoreface of Sapelo Island (Georgia, USA) and produced by the extant semiterrestrial crab Ocypode quadrata (Fabricius, 1787). The longest extant Ocypode trackway (about 100 meters long) unrelated to the hydratation behaviour, was reported from the Coast of Bengal Gulf, India, showing the variability of the trackway morphology related to crossing different substrates (De, 2014: figs. 4, 5).

The exceptionally preserved specimen is the sole trackway among the studied samples that can indisputably be ascribed to a brachyuran crab due to the evidence of characteristic body forms (walking legs, chelipeds, and ventral impression) preserved in the middle of the trace. The structure of the trackways shows that the trace-maker was alive after the resting activity while the tracks continues after the stop, having a different, divergent direction. The comparison of this walking trace with others found in the laminated layers from Valduggia allow us to support our hypothesis that all the trackways having a similar arrangement and form might belong to brachyuran crabs having different sizes and behaviours.

\section{Other invertebrate biostructures of the ichnofacies}

Burrows (?Skolithos and Thalassinoides): 4 slabs (MSNM i28017: $230 \times 250 \mathrm{~mm}$ ); MSNM i28019: 340 $\mathrm{mm} \times 230 \mathrm{~mm}$ ); MSNM i28021: $260 \mathrm{~mm} \times 150 \mathrm{~mm}$ ); MSNM i28046: $270 \mathrm{~mm} \times 75 \mathrm{~mm}$ ).

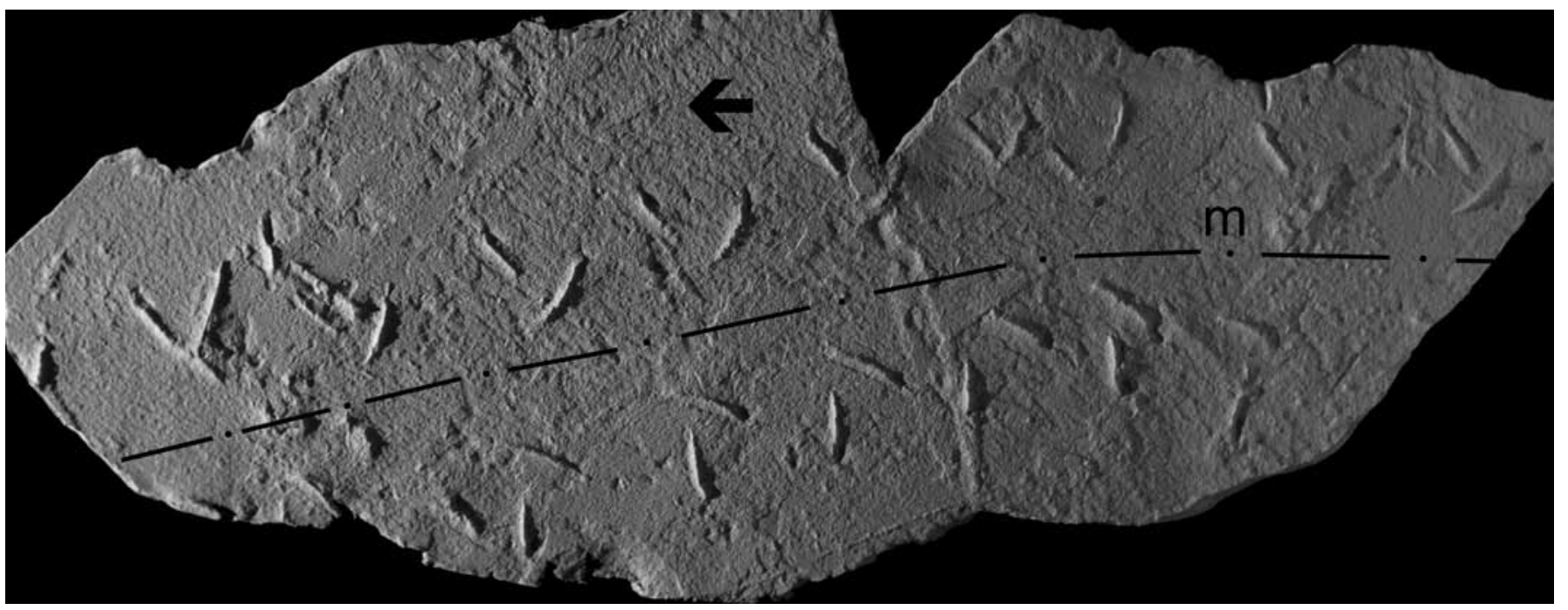

Fig; 16 - MSNM i28026. Straight asymmetric wide trackway with an interior very light possible shell drag trace, diagnostic of fossil and extant land hermit crab walking traces (?Coenobichnus) $(\times 0.3)$. 

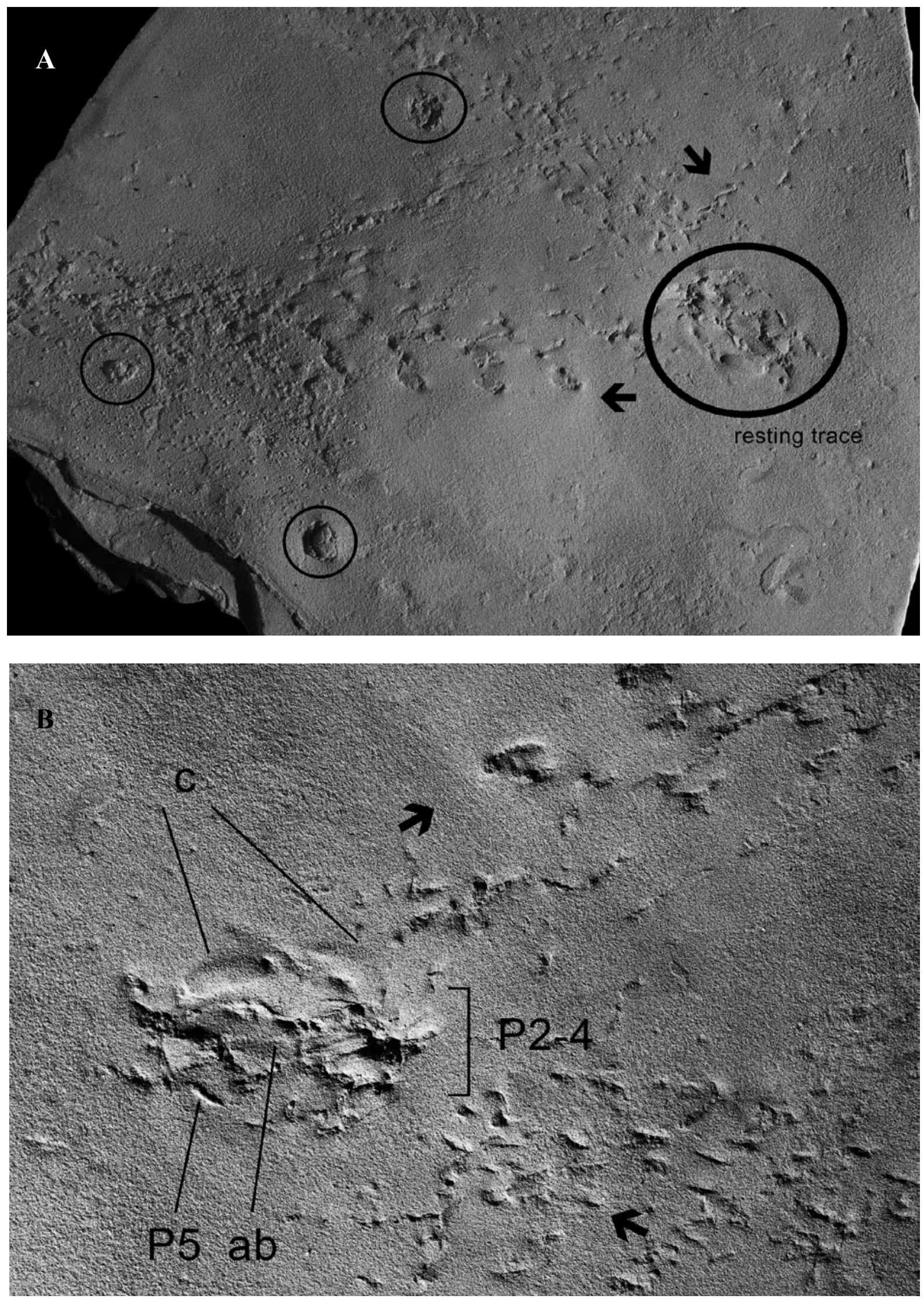

Fig. 17 - MSNM i28020. A) Slab preserving a crab trackway with interconnected resting trace, and vertical subrounded burrows (?Skolithos) (x 0.5). B) The impression of the carapace surrounded by the walking legs and the chelipeds gathered frontally preserved between the interconnected walking tracks, correlated to the same trace-maker (c: cheliped; P2-P5: walking legs; ab: pleon) (natural size). 
One slab (MSNM i28017) shows two vertical, subrounded small burrows (diameter about $16 \mathrm{~mm}$ ) filled with brown argillaceous material (possibly due to the presence of iron oxides), and crossing the total thickness of the slab (?Skolithos, sensu Frey \& Pemberton,1987; Pemberton et al., 1992), indicating fossorial activity (Fig. 13). Subrounded burrows of similar form (diameter about $15 \mathrm{~mm}$ ) are also present on slab MSNM i28020 (Fig. 17A).

In both specimens the burrows are associated with arthropod trackways not directly connected with the burrows, and referable to the same type of trace-makers previously described at pag. 39 .

Two incomplete slabs (MSNM i28019 and MSNM i28021) preserve exogenic, mostly horizontal, sinuous, and Y-shaped burrows, developed as a trail on the lower bedding plane of the slabs (?"Thalassinoides"), partially compressed and subelliptical in transverse section (maximum diameter about $13 \mathrm{~mm}$ ). These structures are crossed by some true crustacean trackways also comparable with those previously described at pag. 39 (Figs. 8 and 18). Particularly specimen MSNM i28021 (Fig. 18) is very similar also to trackway Type 2 reported by Dam (1990: 135, fig. 12D), from a subtidal environment of the lower Jurassic of East Greenland.

One slab (MSNM i28022 rear) preserves among different crustacean trackways a partial, undulating, horizontal short trail rounded in transverse section, narrower than the previous ones (diameter about $4 \mathrm{~mm}$ ), similar to those produced by feeding/locomotion (Pascichnia) behaviour by possible worms (Fig. 9).

The slab (MSNM i28046) also preserves a short, similar partial horizontal trail (diameter about $2.5 \mathrm{~mm}$ ), crossing some typical straight, symmetric ripplemarks, indicating an unidirectional lower flow regime in this level (Fig. 19).

Relevant is also the occurrence of a simple trace fossil (MSNM i28301, maximum diameter $10 \mathrm{~mm}$ ), preserved in full relief, and covered with longitudinal and thin, subparallel wrinkles, irregular and discontinuous, recovered on a slab without trackways; generally they show a concentration of frustules and a diffuse redbrown colour induced by the presence of iron oxides. This convex hypichnial ichnospecies (Fig. 4B) has been

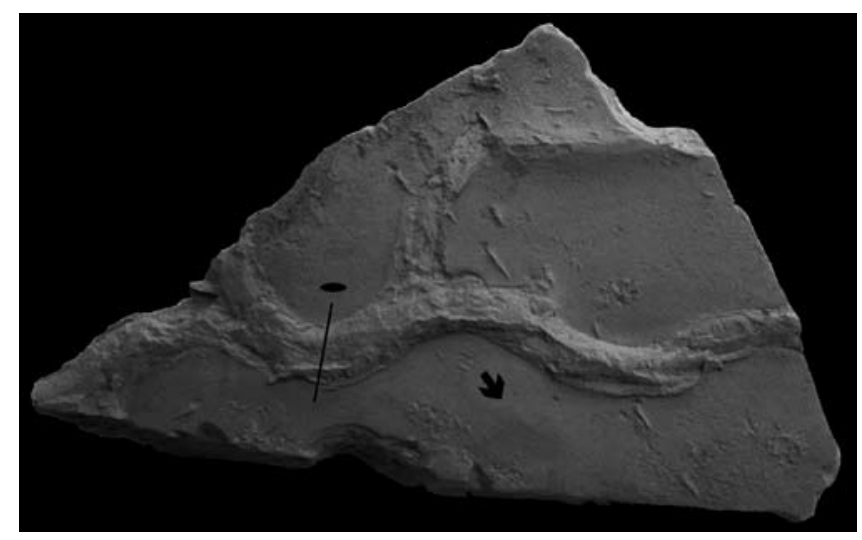

Fig. 18 - MSNM i28021. Exogenic mostly horizontal, sinuous and Y-shaped burrow (?"Thalassinoides"), crossed by a crab trackway $(\times 0.3)$. identified by P. Monaco (pers. comm., 2015) as Halopoa cf. H. imbricata Torell, 1870, for the typical shape of wrinkles that in our sample are long and anastomosing (Monaco, 2014; Monaco \& Trecci, 2014; Rihai et al., 2014). Halopoa s.s. usually occurs as long, unbranched and generally horizontal, 5-10 $\mathrm{mm}$ wide, tunnels with longitudinal, discontinuous ridges or wrinkles, composed of cylindrical probes that imperfectly overlap the central tube. The external shape is typically irregular (see Seilacher, 2007, Pl. 46). Halopoa was probably generated by the feeding action of a soft-bodied, wormlike organism preferring a water-saturated $\mathrm{mud} / \mathrm{silt}$ sediments very rich in organic matter (Monaco, 2010). As reported by Monaco \& Trecci (2014), Halopoa occurred in fine-grained and rippled facies of turbidite deposits as hypichnial traces in a favorable substrate rich in organic matter and few sand.

\section{DISCUSSION}

According to different authors, it is impossible to link fossil trace with the real trace-maker in the absence of body remains at the end of the trackways. Only some speculative suggestions are here proposed based upon the palaeontological and neoichnological data.

According to sedimentological and lithological data, a characteristic beachface, more likely attributable to an inner-supratidal environment influenced by emergence and by irregular influx of nutrient rich river water where decapod fauna proliferated, can be inferred for the Valduggia area during the Pliocene.

The occurrence of hypichnial Halopoa cf. H. imbricata suggests a soft substrate where worm-like organisms lived and proliferated.

Moreover, the study of the fossil ichnofacies, compared with similar extant biocoenoses and neo-ichnofacies, allows us to indicate some brachyuran crab(s) as the most likely trace-makers of the majority of the studied sedimentary structures, in conformity with the typology and form of the traces, and behaviours reflected by the trackways (Frey et al., 1987; Pirrie et al., 2004).

The preservation of the traces and their fossilisation were probably due by rapid dehydration of the sedimentary surface due to seasonally favourable conditions and

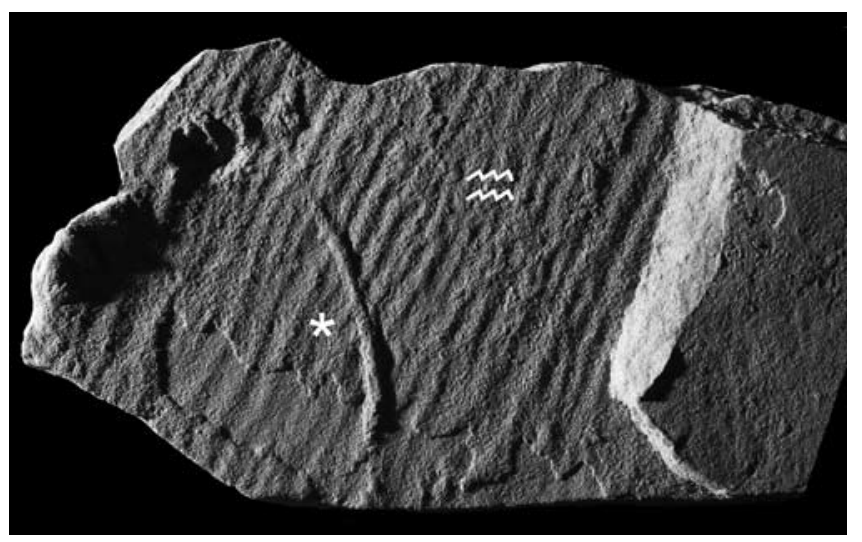

Fig. 19 - MSNM i28046. Partial horizontal (?worm) subcircular burrow $(*)$ crossing tiny, symmetric ripplemarks $(\times 0.5)$. 
to the "...ebbing of the tide and corresponding drainage of pore water (that) caused the best preserved traces..." (Martin, 2006: 57), possibly similar to those observed today for example along the sandy shoreface surfaces of Sapelo Island (Georgia, USA) (Martin, 2006: 64). The presence of an exceptional specimen preserving a walking trail interconnected with a resting trace with the ventral impression of the trace-maker, confidently assigned to a decapod brachyuran, allows us also to postulate a more precise analysis and discussion when compared with the behaviour of the extant representative of the Ocypodidae (Decapoda, Brachyura).

Indeed, the studies on the tracks reported by Martin (2006) from the Georgia costal line (USA) for the extant semiterrestrial Ocypode quadrata during rehydrating and respiration behaviour, if compared with the studied specimen (MMSN i28020), seem to show interesting and unambiguous affinities. The arrangement of the walking legs around the print of the body, the arrangement of the chelipeds gathered frontally, and the general form of the trackway are very similar to the traces of the extant Ocypode as figured by Martin (2006: 60, Fig. 2), and also to those reported from the Bengal Gulf, India, by De (2014: Fig. 5).

From another perspective, we remark that the subrectangular form of the palm of the chelae, with the left more elongate than the right (as seen from the palm impressions), are characters atypical of Ocypode. As a second, but less definitive observation, no fossil representative of this genus or other semiterrestrial decapods has ever been reported from the palaeo-Adriatic Gulf. This may due to the rarity of preserved sedimentary marine foreshore environments in this area. So, in other way, the resting trace might also be related to the behaviour of other semiterrestrial or marine brachyurans feeding along the tidal line. For example, the extant representatives of the invasive green crab Carcinus maenas (Linnaeus, 1758), widespread among other different species along the mud-sandy shore zones of the Mediterranean coasts, hide themselves in the beach with similar behaviour (Bravo et $a l ., 2007)$ but with a different outcome. This activity creates less detailed resting trace, but does not preserve the true outline of the body and legs of the burrower (Pasini, pers. obs., 2014, along the intertidal zone of the Venice Lagoon, in the northern Adriatic Sea).

In the absence of other similar evidence and possible comparisons, we prudently assign the studied specimen to an indeterminate semiterrestrial brachyuran resting trace, possibly allied to a specific behaviour (?rehydrating-respiration, ?feeding or other), with a preference for the first hypothesis.

Finally, we note that most of the studied trails (considering the different ages, environments, and geographic areas) shows more close morphological affinities with the brachyuran trackways "Type 2" reported by Karasawa et al. (1990), and those reported by Imaizumi (1967) and Matsuoka et al. (1993) and with the ichnogenus Foresterichnus Pirrie, Feldmann \& Buatois, 2004.

One specimen (MSNM i28026), showing an asymmetric pair of two paired traces and a characteristic median (possible) shell drag trace, is here explained as a land hermit crab trackway that could be correlated in general arrangement and typology to Coenobichnus Walker, Holland \& Gardiner, 2003 isp. Moreover a problematic trace is tentatively assigned to an indeterminate marine organism (Saerichnites-like). The occurrence of hypichnial Halopoa cf. H. imbricata has been reported in shallow marine deposits for the first time.

\section{CONCLUSIONS}

The present study reports a well-preserved rare and peculiar ichnofacies from the inter-supratidal Pliocene deposits of Valduggia (Vercelli), in the Western Padanian Gulf of the paleo Adriatic Sea (northern Italy). Rich activity, mostly by decapod crustaceans, is clearly documented in this peculiar environment and is referable to a shoreface influenced by a river supply.

Lacking sufficiently substantial details and comparative material to allow such taxonomic classification, we prefer to limit this report to objective observations and comparisons. Typological and general morphology allow us to ascribe in a speculative way the majority of the studied arthropod trackways to the activity of indeterminate semiterrestrial brachyurans (?Ocypodidae), and one to a terrestrial indeterminate hermit crab (?Coenobichnius isp.). One problematic trace is tentatively assigned to an indeterminate marine organism (?Samrichnites-like). These kinds of traces are reported for the first time in the Pliocene Mediterranean record, enlarging our general knowledge of the poorly known palaeoichnology and behaviour of some semiterrestrial fossil decapod crustaceans.

\section{Acknowledgements}

We wish to thank Giorgio Faglia (Serravalle Sesia, NO), Ennio Lavè (Borgomanero, NO), Mauro Valentini (Oleggio, NO), and Luca Vaona (Cavallirio, NO), for useful information on the Valduggia outcrops; P. Monaco, Department of Physics and Geology (Perugia University, Italy), for identification and useful suggestions on Halopoa isp.; K. Matsuoka, Toyohashi Museum of Natural History (Aichi, Japan), for offering detailed images of the Shidara specimens; R. M. Feldmann, Geology Department, Kent State University, Ohio, for useful suggestions about the first draft of the manuscript.

\section{REFERENCES}

Billings E., 1866 - Catalogue of the Silurian Fossils of the Island of Anticosti, with descriptions of some new genera and species. Geological Survey of Canada, Montreal.

Bravo M.A., Cameron B. \& Metaxas B., 2007 - Salinity tolerance in the early larval stages of Carcinus maenas (Decapoda, Brachyura), a recent invader of the Bras d'Or Lakes, Nova Scotia, Canada. Crustaceana, 80: 475-490.

Carraro F., 1992 - Evoluzione Plio-Quaternaria. In: Guide Geologiche Regionali (3)- Le Alpi dal Monte Bianco al Lago Maggiore. A cura della Società Geologica Italiana, 82-91. BE-Ma Editrice. 
Curran R. A., 1984 - Ichnology of Pleistocene carbonates on San Salvador, Bahamas. Journal of Paleontology, 58: 312-321.

Dam G., 1990 - Taxonomy of trace fossils from the shallow marine Lower Jurassic Neill Klinter Formation, East Greenland. Bulletin of the Geological Society of Denmark, 38: 119-144.

De C. \& Mathur U. B., 2007 - Quaternary geological evolution of Gujarat with special reference to the Banas River basin and Bhavnagar coast, Gujarat, western India. Memoirs of the Geological Survey of India, 134: $1-134$.

De C., 2014 - Longest crab trackways from the Bay of Bengal Coast, India: their geological and geotechnical applications. Paleontologia Electronica, 17 (2), 31A: $1-19$.

Frey R. W. \& Pemberton S. G., 1987 - The Psilonichnus ichnocoenose, and its relationship to adjacent marine and nonmarine ichnocoenoses along the Georgia coast. Bulletin of Canadian Petroleum Geology, 35: 333-357.

Frey R. W. \& Howard J. D., 1988 - Beaches and beachrelated facies, Holocene barrier islands of Georgia. Geological Magazine, 125: 621-640.

Full R. J. \& Blickman R., 1985 - Ghost crab locomotion: the efficiency of traveling sideways. American Zoologist, 55A: 25.

Garassino A., De Angeli A., Gallo M. L. \& Pasini G., 2004Brachyuran and anomuran fauna from the Cenozoic of Piedmont (NW Italy). Atti della Società italiana di Scienze naturali e del Museo civico di Storia naturale in Milano, 145 (2): 251-281.

Garassino A., De Angeli A., Pasini G. \& Tangocci F., 2010 - Ocypode italica n. sp. (Crustacea, Decapoda, Brachyura, Ocypodidae) from the Piacentinan (middle Pliocene) of Tuscany (Central Italy). Atti della Società italiana di Scienze naturali e del Museo civico di Storia naturale in Milano, 151 (2): 135-144.

Garassino A. \& Pasini G., 2013 - Calappa granulata (Linnaeus, 1758) (Crustacea, Decapoda, Brachyura, Calappidae) and Astiplax aspera n. gen., n. sp. (Crustacea, Decapoda, Brachyura, Goneplacidae) from the Asti sands Fm. (Late Pliocene) of S. Pietro (Asti, Piedmont, NW Italy). Boletín de la Sociedad Geológica Mexicana, 65 (2): 329-334.

Imaizumi R., 1967 - On some Lebensspuren from the Tatsunokuchi Formation at Tatsunokuchi Gorge, Sendai, Miyagi Prefecture. Commemorative Association of Prof. Ichirô Hayasaka's $77^{\text {th }}$ Birthday (ed.), 205-210, pl. 17. Commemorative Association of Prof. Ichirô Hayasaka's $77^{\text {th }}$ Birthday, Kanazawa. (in Japanese).

Karasawa H., Okumura Y. \& Naruse A., 1990 - Discovery of crab footprints from the Miocene Mizunami Group, central Japan. Bulletin of the Mizunami Fossil Museum, 17: 93-96. (in Japanese)

Martin A. J., 2006 - Resting traces of Ocypode quadrata associated with hydration and respiration: Sapelo Island, Georgia, USA. Ichnos, 13: 57-67.

Martin A. J., 2013 - Life Traces of the Georgia Coast. Reveling the Unseen Lives of Plants and Animals. Bloomingtoo, Indiana, Indiana University Press.
Matsuoka K., Karasawa H., Yoshimura, A., Ieda K., \& Collaborative Research Group for the Shitara Basin, 1993 - Footprint fossils discovered from the Miocene Shidara Group, Toei-cho, Kitashitaragun, Aichi Prefecture, Japan. Science Report of the Toyohashi Museum of Natural History, 3: 27-36. (In Japanese).

Monaco P., 2014 - Taphonomic aspects of the radial backfill of asterosomids in Oligo-Miocene turbidites of Central Italy (Northern Apennines). Rivista Italiana di Paleontologia e Stratigrafia, 120 (2): 215-224.

Monaco P. \& Trecci T., 2014 - Ichnocoenoses in the Macigno turbidite basin system, Lower Miocene, Trasimeno (Umbrian Apennines, Italy). Italian Journal of Geosciences, 133 (1): 116-130.

Noda H. \& Okamoto K., 1988 - Crustacean racking imprints from the Oligocene Taoyama Formation in Yamaguchi Prefecture, southwest Japan. Annual Report of the Institute of Geoscience, the University of Tsukuba, 14: 51-55.

Pasini G. \& Garassino A., 2009 - First record of Maja squinado (Herbst, 1788) (Decapoda, Brachyura, Majidae) from the Pliocene of Masserano, Biella (Piemonte, NW Italy). Atti della Società italiana di Scienze naturali e del Museo civico di Storia naturale in Milano, 150 (1): 13-20.

Pasini G. \& Garassino A., 2013 - New record of crabs (Decapoda, Brachyura) from the early Pliocene) of Cassine (Piedmont, northern Italy). Neues Jahrbuch für Geologie und Paläontologie, Abhandlungen, 270 (3): 343-346.

Pasini G. \& Garassino A., 2015a - Petrochirus fabroensis Pasini, Garassino \& De Angeli, 2014 (Anomura, Diogenidae) and Ranina sp. (Brachiura, Raninidae) from the Pliocene of Masserano (Piedmont, NW Ita1y). Natural History Sciences. Atti della Società italiana di Scienze naturali e del Museo civico di Storia naturale in Milano, 2 (1): 47-49. DOI:10.4081/ nhs. 2015.221

Pasini G. \& Garassino A., 2015b - Petrochirus sanctilazzari Pasini, Garassino \& De Angeli, 2014 non Petrochirus fabroensis Pasini, Garassino \& De Angeli, 2014 (Anomura, Diogenidae) from the Pliocene of Masserano (Piedmont, NW Italy). $\mathrm{Na}$ tural History Sciences. Atti della Società italiana di Scienze naturali e del Museo civico di Storia naturale in Milano, 2 (2): 149-150. DOI:10.4081/ nhs. 2015.258

Pasini G. \& Garassino A., 2016 - Ethusa sp. (Decapoda, Brachyura, Ethusidae) from the Pliocene of Valduggia (Vercelli, Piedmont, NW Italy). Natural History Sciences. Atti della Società italiana di Scienze naturali e del Museo civico di Storia naturale in Milano, 3 (1): 53-54. DOI: $10.4081 / \mathrm{nhs} .2016 .262$

Pemberton S. G., MacEachern J. A. \& Frey R. W., 1992 Trace fossil facies models: Environmental and allostratigraphic significance. In: Walker R. G. \& James N. P. (eds.), Facies Models: Response to Sea Level Change ( $2^{\text {nd }}$ edition). Geological Association of Canada: 47-72. 
Pirrie D., Feldmann R. M. \& Buatois L. A., 2004 - A new decapod trackway from the Upper Cretaceous, James Ross Island, Antarctica. Palaentology, 47 (1): 1-12.

Rihai S., Uchmann A., Stow D., Soussi M. \& Lattrache K. B. I., 2014 - Deep sea trace fossils of the OligoceneMiocene Numidian Formation, northern Tunisia. $\mathrm{Pa}$ laeogeography, Palaeoclimatology, Palaeoecology, 414: 155-177.

Seilacher A., 1964 - Biogenic sedimentary structures. In: Approaches to Paleoecology. Imbrie J. \& Newell N. eds., Wiley, New York: 296-316.

Seilacher A., 2007 - Trace Fossil Analysis. Springer Verlag, Berlin.

Walker S. E., Holland S. M. \& Gardiner L., 2003 - Coenobichnus currani (new ichnogenus and ichnospecies): fossil trackway of a land hermit crab, early Holocene, San Salvador, Bahamas. Journal of Paleontology, 77: 576-582. 